\title{
Commentary: Avoiding the fate of King George II: Are we making progress?
}

\author{
William M. DeCampli, MD, PhD
}

\footnotetext{
From the Department of Clinical Sciences, College of Medicine, University of Central Florida, Orlando, Fla; and Division of Cardiothoracic Surgery, Arnold Palmer Hospital for Children, Orlando, Fla. Disclosures: Author has nothing to disclose with regard to commercial support.

Received for publication Nov 9, 2018; accepted for publication Nov 9, 2018; available ahead of print Dec 18, 2018.

Address for reprints: William M. DeCampli, MD, PhD, Division of Cardiothoracic Surgery, Arnold Palmer Hospital for Children, 83 W Miller S, Orlando, FL 32813 (E-mail: William.decampli@ucf.edu).

J Thorac Cardiovasc Surg 2019;158:364-5

$0022-5223 / \$ 36.00$

Copyright $(2) 2018$ by The American Association for Thoracic Surgery

https://doi.org/10.1016/j.jtcvs.2018.11.026
}

What causes aortic dissection? Dr Frank Nicholls must have wondered this when he discovered the finding during an autopsy of George II, King of Great Britain, who died suddenly in October 1760. Two hundred fifty years later, we are still pondering the question. Predisposing factors-hypertension, smoking, atherosclerosis, aortic dilation, male gender, advanced age, bicuspid aortic valve, connective tissue syndromes, and vasculitis/arteritis-have given us clues. More recently, genetic alterations related to inflammation and subsequent vessel wall remodeling (such as those of NOTCH1, ACTA2, FNB1, LRP1, and ULK4) have been found to be associated with dissection. ${ }^{1}$ This potpourri of predisposing factors and genetic association leaves to the imagination the true causal pathway leading to the end point.

Emerel and coworkers ${ }^{2}$ add an additional factor to the pot. The authors used predissection echocardiographic and computed tomography angiographic data and an assumed solid mechanical model of the ascending aorta to calculate and map wall shear stress (WSS) in 7 patients who subsequently sustained aortic dissection. Compared with a control group (imaged for reasons other than aortic disease), the dissection group had greater longitudinal WSS. They mapped the location of the actual dissection origin onto the models and found that it corresponded to the location of maximal longitudinal WSS. The authors ${ }^{2}$ propose that this might serve as a predictive factor for dissection in vulnerable patients.

In a mechanical model of flow through the aorta, the force that results in $99 \%$ of the aortic wall stress is that which is normal (ie, perpendicular) to the inner wall, namely the blood pressure. WSS, on the other hand, is much less forceful, and is directed parallel to the vessel wall. Thus, WSS is certainly not the temporally proximate cause of dissection. Rather, it is well known that WSS is exquisitely sensed and transduced by vascular endothelial cells. WSS either significantly greater than or less than normal values activates gradual structural changes in the vessel wall that can rigid tube, WSS is

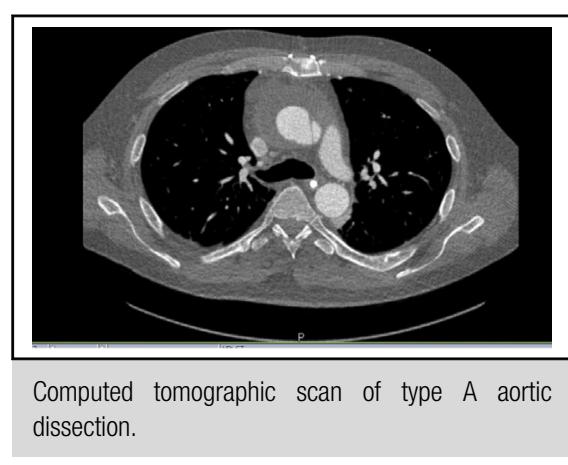

Central Message

A newly discovered association between wall shear stress and aortic dissection may contribute to the prediction and knowledge of mechanism of this disorder.

See Article page 355

become part of the pathophysiology of clinical disorders such as atherosclerosis, aneurysm, and dissection. ${ }^{3,4}$ WSS has been extensively studied in the context of coronary and carotid atherosclerosis and ascending aortic dilation and aneurysm. The current study establishes an association between WSS and aortic dissection.

In a very simple model of steady flow through a straight

$$
\mathrm{WSS}=32 \mu Q / \pi D^{3},
$$

where $\mu$ is dynamic viscosity, $\mathrm{Q}$ is mass flow rate, and D is the vessel diameter. In this simple model, elevated WSS implies either greater flow rate or lesser vessel diameter. In pulsatile flow through a curved elastic vessel, the expression is not so simple because the flow patterns are more complex and time-dependent. Thus, the reasons for elevated WSS in patients susceptible to dissection will depend in a complex manner on aortic geometry, aortic compliance, and left ventricular outflow pattern, as well as rates of change of pressure and velocity. Thus, WSS may be the common link among variables that have already been shown to be associated with dissection, such as aortic length, angle of takeoff of the brachiocephalic artery, and aortic tortuosity (for type $\mathrm{B}$ dissection), and why ascending aortic diameter $>5.5 \mathrm{~cm}$ alone is not a good predictor of type A dissection. ${ }^{5-8}$ The pilot study by Emerel and colleagues ${ }^{2}$ of 7 patients raises the possibility of an interesting association that may aid in putting together the pieces of the puzzle as to what causes 
dissection, how to accurately determine risk, and how to mitigate it long before the catastrophe occurs.

\section{References}

1. Gawinecka J, Schonrath F, von Eckardstein A. Acute aortic dissection: pathogenesis, risk factors and diagnosis. Swiss Med Weekly. 2017;147:w14489.

2. Emerel L, Thunes J, Kickliter T, Billaud M, Phillippi JA, Vorp DA, et al. Predissection-derived geometric and distensibility indices reveal increased peak longitudinal stress and stiffness in patients sustaining acute type A aortic dissection: implications for predicting dissection. J Thorac Cardiovasc Surg. 2019;158: 355-63.

3. Papaioannou T, Stefanadis C. Vascular wall shear stress: basic principles and methods. Hellenic J Cardiol. 2006;46:9-16.

4. Von Knobelsdorff-Brenkenhoff F, Karunaharamoorthy A, Trauzeddel RF, Barker AJ, Blaszczyk E, Markl M, et al. Evaluation of aortic blood flow and wall shear stress in aortic stenosis and its association with left ventricular remodeling. Circ Cardiovasc Imaging. 2016;9:e004038.

5. Shirali A, Bischoff M, Lin H, Oyfe I, Lookstein R, Griepp R, et al. Predicting the risk for acute type $\mathrm{B}$ aortic dissection in hypertensive patients using anatomic variables. J Am Coll Cardiol. 2013;6:349-57.

6. Pape L, Tsai T, Isselbacher E, Oh J, O'Gara P, Evangelista A, et al. Aortic diameter $>5.5 \mathrm{~cm}$ is not a good predictor of type A aortic dissection: observations from the international registry of acute aortic dissection (IRAD). Circulation. 2007;116: 1120-7.

7. Kruger T, Forkavets O, Veseli K, Lausberg H, Vohringer L, Schneider W, et al Ascending aortic elongation and the risk of dissection. Eur J Cardiothorac Surg. 2016;50:241-7.

8. Osswald A, Karmonik C, Anderson J, Rengier F, Karch M, Engelke J, et al. Elevated wall shear stress in aortic type B dissection may relate to retrograde aortic type A dissection: a computational fluid dynamics pilot study. Eur J Vasc Endovasc Surg. 2017;54:324-30. 